complote coverage of the soft X-ray literature for the period 1950-60. Some reforences to earlier work are includod but the general review reforences, listed separately, covor fairly adequately previous work. The first group of roferences in the monograph is of goneral survey and roview papers and books. Tho main list of roferences follows, grouped by year and arranged alphabetically by author within each year. The emphasis is on the application of soft X-ray spectroscopy to the study of valence band olectronic statos in metals and alloys. The spoctral region 25-..800 $\AA$ involving rulod glass grating spectrometers is thereforo of principal interest. Howevor, considerable data have boen gathered, primarily by the Russians, on valence electronic states by moans of highenergy transitions where crystal spectromotors aro satisfactory. Theso roferences and any $\mathrm{X}$-ray work leading to the distribution of valence eloctronic states are included regardloss of the transitions used. In addition to soft $X$-ray data, referencos on all portinent aspocts of the apparatus and experimental problems are included in the bibliography. A number of indoxos aro given at the boginning of the monograph for ready reference to papers containing the specific data to which the bibliography applies. In the literature the spoctra are presented in a variety of energy units, and in compiling the bibliography the units given in the original papors havo boon rotained. A conversion chart of units is appended to the bibliography. It is intended to continue the bibliography and to issue supplements periodically.

\section{Protecting Turtles in Sarawak}

A Government Ordinance now protocts the greater turtles of Sarawak from disturbance, under penalty of a 1,000 dollar fine. This is the penalty for any unauthorized vessel approaching within half a mile of three islands off the coast of Sarawak, Talang Talang Besar, Talang Talang Kochil and Satang Besar, on which the turtles nest. Carefully conservod by the curator of the Sarawak Museum, Dr. Tom Harrisson, the turtles have provided more than twenty million eggs for local consumption in the past fifteen years (World Wildlife News, No. 7; Octobor 1962). Many other eggs have been removed to hatcheries, where the young turtles have been reared safely and released again at sea when they are big enough to fend for themselves.

\section{Incidence and Distribution of Asthma in Australia}

AN analysis was made of asthma cases in public hospitals in Queensland in the year 1957. Asthma was responsible for 2,673 cases, or $1 \cdot 62$ per cent of the total. It predominated in male children and in adults more than 55 years of age. It predominated in females in the intervening years. A striking fall in the male incidence in the second decennium suggested a favourable prognosis for most asthmatic boys. The apparent incidence of asthma varied considerably from place to place. The variation could not be explained simply in terms of latitude, altitude, temperature, rainfall or distance from the coast. Some of tho variation between hospitals was probably due to different criteria for admission. The seasonal distribution changed significantly at about the Tropic of Capricorn. To the south, the main incidence was in autumn; to the north, no seasonal patterns had a wido prevalonco. The investigators, Drs. E. H. Derrick and R. H. Thatcher, showed that an rtiological study of asthma must take into account variation in the complex of causes including sex, age, season and locality (Seventeenth Annual Report of the Council of the Queensland Institute of Medical Research for the year ended 30th June, 1962. Pp. 12. Brisbane: Queensland Institute of Medical Research, 1962).

\section{The Society for Visiting Scientists}

The report of the secretarios on bohalf of the Council of tho Society for Visiting Scientists made to the fifteenth general meeting on December 11 rofers to the success of the three discussion meetings dealing, respectively, with colour television, the turkey $\mathrm{X}$ disease, and matching mon and machinos. Activities were somewhat restricted by the change of premises from Old Burlington Street to 19 Albomarle Street, and reference is again made to the difficulty of finding now and adoquate sources of incomo.

\section{The Scottish Field Studies Association :}

Programme of Courses

The Scottish Field Studies Association has arranged the following courses during 1963: Garth: goography (April 13-20); spring in tho Highlands (May 18-25); geology of Glen Lyon (June 8-15); insect natural history (June 29-July 6); grasses, rushos and sedges (July 6-13); mountain and moorland ecology (August 3-10); mountain flowers (August 10-17); plant ocology (August 17-24); lichons (September 7-14); Isles of Great Cumbrae: seashore biology (May 11-18); marine biology (June 1-8, June 8-15, August 24-31); Black Isle: geography (June 1-8); Pitlochry: archæology (June 1-8); Isle of Arran: birds of Arran (April 13-20); geology of Arran (June 1-8, September 7-14); wild flowers (July 6-13); Strathpeffer : Highland birds (June 8-15); geographical field studies (July 6-13); North Ballachulish: geology of Glencoe (July 6-13); Alnmouth: birds of Northumborland (June 1-8); a geographical survoy of the Hebridean highlands and islands (April 11-17). Further information can be obtained from the Scottish Field Studies Association, 179 West Regent Street, Glasgow, C.2.

\section{Announcements}

Dr. Bernard Keisch, researoh physicist with the Phillips Petroleum Company's Atomic Energy Division at Idaho Falls, has been appointed senior seientist at the Nuclear Science and Engineering Corporation, Pittsburgh, Pa.

Changes of name of subsidiary companies of the Derritron Group have been announced as follows: Beme Research and Development Ltd., to Derritron Research and Development Ltd.; Chapman Ultrasonics Ltd., to Derritron Ultrasonics Ltd. (managing director, Mr. C. T. Chapman); Doran Instrument Co. Ltd., to Derricron Instruments Ltd.; Electronic Vibrators Ltd., to Derritron Electronic Vibrators Ltd.; L. S. B. Components Ltd., to Derritron Transformers Ltd.

A PRogramme of twelve courses on the use of isotopes has been arranged by the Atomic Energy Research Establishment Isotope School during the period Fobruary 11December 13. The courses will range between five and twenty-three days in length, with tuition fees between

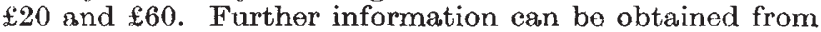
the Wantage Research Laboratory (A.E.R.E.), Wantage, Berkshire.

A symposium on "Communications in Industrial Relations", organized by the Central London Productivity Association in conjunction with the Department of Management and Social Science, Northampton College, will be held at the Northampton College of Advanced Technology, London, on January 30. Further information can be obtained from Miss C. M. Burnell, Room I01, Northampton College of Advanced Technology, St. John Street, London, E.C.1.

Erratum. In the communication by C. Chlouvorakis entitled "Adipose Tissue Lipoprotein Lipase Activity in Rats of Two Different Ages", which appeared on p. 1103 of the December 15 issue of Nature, the tenth paragraph should read "The average enzyme activity so defined was found to bo $19.36 \pm 8.25$ (mean $\pm S . D$. ) units in young, and $3.81 \pm 2.92$ (mean \pm S.D. as above) units in old rats $(t=\overline{5} \cdot 3, P<0.0001) "$. 